\title{
Mounier-Kuhn syndrome: a rare and often overlooked cause of bronchial dilation and recurrent respiratory tract infections
}

\author{
Síndrome de Mounier-Kuhn: uma causa rara e muitas vezes negligenciada \\ de dilatação brônquica e de infecções recorrentes do trato respiratório
}

\section{Shailendra Kapoor}

\section{To the Editor:}

1 read with great interest the recent article by García et al. ${ }^{(1)}$ It should be noted that one rare, often overlooked and underrecognized, cause of respiratory tract infections and bronchial dilation is Mounier-Kuhn syndrome (MKS). The primary feature of MKS, also known as "tracheobronchopathia malacia", is congenital tracheal dilation accompanied by dilation of the main bronchi. ${ }^{(2)}$ The dilation occurs secondary to muscular layer degeneration of the trachea and bronchi. Tracheal dilations as large as $36 \mathrm{~mm}$ have been reported in MKS. The syndrome most often affects adults between 30 and 40 years of age, predominantly males. ${ }^{(3)}$ It is rarely diagnosed in pediatric patients and usually accompanies disorders such as cutis laxa. There are numerous presentations of MKS. For instance, Randak et al. recently reported the case of a patient with MKS who developed concurrent tracheal diverticula. ${ }^{(4)}$

Patients with MKS typically develop recurrent lower respiratory tract infections. Such patients can also develop rare forms of bacterial infections. For instance, Arroyo-Cózar et al. recently described the case of a 75-year-old male with MKS who developed a respiratory infection with Alcaligenes xylosoxidans. ${ }^{(5)}$ Recurrent bronchiectasis and pneumonia are frequently seen. Patients might also present with intermittent dyspnea. Coughinduced syncope is often seen. Hemoptysis is rare but has been reported. Pulmonary fibrosis can further complicate the course of the disease, as can emphysema. Rapid progression of the disease can result in respiratory failure. Although recently reported by Dincer et al. ${ }^{(6)}$ vocal cord paralysis is rarely seen in MKS patients.

lmaging with $\mathrm{CT}$ goes a long way toward confirming the diagnosis of MKS.(7) Such imaging, especially HRCT scans, typically reveal widening of the trachea and main bronchi. When the tracheal diameter exceeds $30 \mathrm{~mm}$, a formal diagnosis of MKS can be made. ${ }^{(8)}$ Other diagnostic criteria include a right main bronchus diameter greater than $24 \mathrm{~mm}$ or a left main bronchus diameter greater than $23 \mathrm{~mm}$. The widening is accompanied by marked bronchiectasis. ${ }^{(3,6)}$ A few patients develop pneumothorax. Some patients initially present with a pneumothorax that reveals the underlying MKS. For instance, in a recent report of the case of a 54-year-old patient presenting with left-sided pneumothorax, further evaluation revealed the underlying cause to be MKS. ${ }^{(9)}$ Significantly dilated airways are typically seen on bronchoscopic evaluation. The results of pulmonary function tests can be normal or abnormal.

The management of MKS primarily involves the institution of supportive measures. Antibiotics need to be started immediately in patients with respiratory tract infections. ${ }^{(5)}$ Chest physiotherapy is advised in most patients. Laser therapy is another emerging alternative. Dutau et al. recently reported the successful management of a patient with MKS by the use of yttrium-aluminum-garnet laser endoscopically. ${ }^{(10)}$ Collapse of the tracheal airway might necessitate endobronchial stenting. Odell et al. recently reported considerable success with such stenting. ${ }^{(11)}$ Another surgical procedure that can be considered in patients with severe forms of MKS is tracheobronchoplasty.

It is obvious that MKS is a rare yet significant cause of respiratory tract infections. It should be included in the differential diagnosis of patients with lower respiratory tract infections and concurrent tracheal dilation on imaging.

\section{Shailendra Kapoor \\ Physician, Private Practice, Chicago, 1L, USA}

\section{References}

1. González-García M, Maldonado Gomez D, Torres-Duque CA, Barrero M, Jaramillo Villegas C, Pérez JM, et al. 
Tomographic and functional findings in severe COPD: comparison between the wood smoke-related and smokingrelated disease. J Bras Pneumol. 2013;39(2):147-54. http://dx.doi.org/10.1590/S1806-37132013000200005 PMid:23670499

2. Dalar L, Eryüksel E, Kosar F, Karasulu AL, Urer N, Sökücü $\mathrm{SN}$, et al. Central airway obstruction due to malignant fibrous histiocytoma metastasis in a case with MounierKuhn syndrome. Tuberk Toraks. 2012;60(2):167-71. http://dx.doi.org/10.5578/tt.2458 PMid:22779939

3. Marchiori E, Sousa AS Jr, Zanetti G, Hochhegger B. Mounier-Kuhn syndrome: The role of bronchiectasis in clinical presentation. Ann Thorac Med. 2012;7(1):51. http:// dx.doi.org/10.4103/1817-1737.91549 PMid:22347353 PMCid:PMC3277044

4. Randak CO, Weinberger M. A child with progressive multiple tracheal diverticulae: a variation of the MounierKuhn syndrome. Pediatr Pulmonol. 2013;48(8):841-3. http://dx.doi.org/10.1002/ppul.22663 PMid:22949127

5. Arroyo-Cózar M, Ruiz-García M, Merlos EM, Vielba D, Macías E. Case report: respiratory infection due to Alcaligenes xylosoxidans in a patient with Mounier-Kuhn syndrome [Article in Spanish]. Rev Chilena Infectol. 2012;29(5):570-1. http://dx.doi.org/10.4067/S071610182012000600019 PMid:23282506

6. Dincer HE, Holweger JD. Mounier-Kuhn syndrome and bilateral vocal cord paralysis. J Bronchology Interv Pulmonol. 2012;19(3):255-7. http://dx.doi.org/10.1097/ LBR.0b013e318261009e PMid:23207474

7. Jaiswal AK, Munjal S, Singla R, Jain V, Behera D. A 46-year-old man with tracheomegaly, tracheal diverticulosis, and bronchiectasis: Mounier-Kuhn syndrome. Lung India. 2012;29(2):176-8. http://dx.doi.org/10.4103/09702113.95337 PMid:22628937 PMCid:PMC3354496

8. Kent BD, Sulaiman 1, Akasheh NB, Nadarajan P, Moloney E, Lane SJ. An unusual cause of spontaneous pneumothorax: the Mounier-Kuhn syndrome. Ir Med J. 2011;104(5):152-3. PMid:21736094

9. Celik B, Bilgin S, Yuksel C. Mounier-Kuhn syndrome: a rare cause of bronchial dilation. Tex Heart lnst J. 2011;38(2):194-6. PMid:21494536 PMCid:PMC3066798

10. Dutau H, Maldonado F, Breen DP, Colchen A. Endoscopic successful management of tracheobronchomalacia with laser: apropos of a Mounier-Kuhn syndrome. Eur J Cardiothorac Surg. 2011;39(6):e186-8. http://dx.doi. org/10.1016/j.ejcts.2011.01.074 PMid:21382725

11. Odell DD, Shah A, Gangadharan SP, Majid A, Michaud G, Herth F, et al. Airway stenting and tracheobronchoplasty improve respiratory symptoms in Mounier-Kuhn syndrome. Chest. 2011;140(4):867-73. http://dx.doi.org/10.1378/ chest.10-2010 PMid:21493699

\section{Respuesta de los autores:}

Luego de leer la interesante descripción del síndrome de Mounier-Kuhn, en la cual cita el artículo de las diferencias tomográficas y funcionales entre la EPOC severa relacionada con humo de leña y con cigarrillo, es importante aclarar que hay diferencias significativas en el compromiso de la vía aérea entre los pacientes con este síndrome y la EPOC por humo de leña. Aunque las dilataciones y engrosamiento bronquial son frecuentes en la EPOC por exposición a humo de leña, no encontramos en las imágenes tomográficas dilatación de la tráquea y los bronquios principales, ${ }^{(1)}$ que es la principal característica del síndrome de MounierKuhn. Los hallazgos en nuestras pacientes de compromiso bronquial y atelectasias, sin daño aparente de tráquea o bronquios fuente, están de acuerdo a la descripción realizada por Moreira et al. ${ }^{(2)}$ en otro artículo del mismo número de la revista. Adicionalmente, los pacientes con EPOC relacionada con el humo de la leña comparten algunas características clínicas con la EPOC por tabaquismo e infrecuentemente se presentan infecciones bacterianas por gérmenes inusuales. Por la presentación de bronquiectasias tanto en la EPOC por leña como en el síndrome de Mounier-Kuhn, las dos entidades deben tenerse en cuenta en el diagnóstico diferencial del adulto con enfermedad bronquial crónica.

\section{Mauricio González-García Médico, Fundación Neumológica Colombiana, Bogotá, Colombia}

\section{Referencias}

1. González-García M, Maldonado Gomez D, Torres-Duque CA, Barrero M, Jaramillo Villegas C, Pérez JM, et al. Tomographic and functional findings in severe COPD: comparison between the wood smoke-related and smokingrelated disease. J Bras Pneumol. 2013;39(2):147-54. http://dx.doi.org/10.1590/S1806-37132013000200005 PMid:23670499

2. Moreira MA, Barbosa MA, Queiroz MC, Teixeira Kl, Torres $\mathrm{PP}$, de Santana Júnior PJ, et al. Pulmonary changes on HRCT scans in nonsmoking females with COPD due to wood smoke exposure. J Bras Pneumol. 2013;39(2):155-63. http://dx.doi.org/10.1590/S1806-37132013000200006 PMid:23670500 